\title{
Autoimmune Haemolytic Anaemia and Mefenamic Acid Therapy
}

\author{
G. L. SCOTT,* M.B., M.R.C.P. ; A. B. MYLES, $\dagger$ M.B., M.R.C.P. ; P. A. BACON, $\ddagger$ M.B., M.R.C.P.
}

\begin{abstract}
Summary: Three patients developed autoimmune $\checkmark$ haemolytic anaemia while being treated with mefenamic acid. In each case the autoimmune haemolytic anaemia was of the warm antibody $\gamma \mathrm{G}$ type, and the antibodies had some rhesus specificity. All three patients recovered when the drug was withdrawn.

Attempts to inhibit or enhance the activity of the antibody in vitro were unsuccessful.

Direct antihuman globulin tests were made in. the red cells of 36 patients receiving long-term mefenamic acid therapy, but only one was found to be transitorily positive.
\end{abstract}

\section{Introduction}

Haemolytic anaemia due to a drug-dependent immune mechanism is known to be a complication of treatment with a number of drugs, and a true autoimmune haemolytic anaemia may occur in patients treated with methyldopa (Worlledge, Carstairs, and Dacie, 1966).

This report describes the occurrence of autoimmune haemolytic anaemia in three patients, each of whom had been treated for a long period with mefenamic acid (Ponstan), an analgesic drug used in treatment of musculoskeletal disorders. The similarity in the serological findings, and the rapid and complete recovery made by all three patients after withdrawal of the drug, suggest that mefenamic acid might have been responsible for the autoimmune haemolytic anaemia.

\section{Case 1}

A 57-year-old woman who had been treated with mefenamic acid $1.5 \mathrm{~g}$. daily continuously for two years for osteoarthritis developed severe diarrhoea and anaemia. On admission she was anaemic and jaundiced without splenomegaly. Haematological investigations: haemoglobin 5.3 g./100 ml., P.C.V. 17\%, M.C.H.C. $31 \%$, reticulocytes $36 \%$, white cell count $10,800 / \mathrm{cu}$. mm. The red cells were markedly spherocytic, and autoagglutination was noted. Tests for Heinz bodies, L.E. cells, and antinuclear factor were negative. Serological investigations: the antihuman globulin test was strongly positive with a broad-spectrum antihuman globulin serum (Hyland) and a specific anti- $\gamma \mathrm{G}$ serum, and weakly positive with an anti-non-gamma serum. Free antibody was detected in her serum by the indirect antiglobulin test with normal group $\mathrm{O}$ cells and by using ficin-treated group $O$ cells. No haemolytic activity could be detected with normal or enzyme-treated cells. Tests on the free antibody and on antibody eluted from her red cells showed it to have a specific anti-e component and a weak non-specific component. The Donath-Landsteiner test was negative.

Mefenamic acid was stopped on admission and prednisone $40 \mathrm{mg}$. daily started. The diarrhoea ceased within 24 hours and she made a rapid recovery. Steroids were withdrawn after five weeks without any recurrence of anaemia. The direct antihuman globulin test remained positive for five months and then became negative. Free antibody could be detected in her serum while the antihuman globulin test was positive. She has remained well for 18 months without any recurrence of haemolysis but has taken no more mefenamic acid.

* Lecturer in Haematology, St. Thomas's Hospital, London S.E.1. + Senior Registrar, West London Hospital, London W.6.

₹ Registrar, West London Hospital, London W.6. Present address: St. Bartholomew's Hospital, London E.C.1.
Case 2

A 53-year-old man with a six-year history of rineumatoid arthritis had been treated with prednisone 8-15 mg. daily for five years and mefenamic acid $1.5 \mathrm{~g}$. daily for 12 months. Three weeks before admission he developed diarrhoea. On examination he was jaundiced and anaemic but had no splenomegaly. Haematological investigations: haemoglobin $7.9 \mathrm{~g} . / 100 \mathrm{ml}$., reticulocytes $37 \%$, white cell count $11,000 / \mathrm{cu}$. mm. The red cells were spherocytic and some contained a few Howell-Jolly bodies. E.S.R. was 136 $\mathrm{mm}$. in one hour, differential agglutination titre 1:512. Tests for antinuclear factor and L.E. cells were negative. Serological investigations (National Blood Transfusion Service, Sutton): "The direct antihuman globulin test was strongly positive, The (antibody) globulin coating the patient's cells was mainly of the 'warm" gamma variety. There was also evidence of a cold autoantibody in the serum. The serum contained autoantibodies which had anti-e specificity. A weak non-specific autoantibody was also present."

Mefenamic acid was stopped and treatment with azathioprine $200 \mathrm{mg}$. daily was started. He made a rapid haematological response, but the direct antihuman globulin test remained positive for nine months. There has been no recurrence of haemolysis in 16 months, though he has taken no more mefenamic acid.

\section{Case 3}

A 53-year-old man with rheumatoid arthritis who had been treated with mefenamic acid continuously for 16 months developed symptoms of anaemia. Haematological investigations: haemoglobin 5.3 g. $/ 100 \mathrm{ml}$., reticulocytes $25 \%$, serum bilirubin $1.7 \mathrm{mg} . / 100 \mathrm{ml}$., serum haptoglobulin less than $20 \mathrm{mg} . / 100 \mathrm{ml}$. A few Heinz bodies were present. L.E. cells were negative. Serological investigations (National Blood Transfusion Service, Lancaster, Subcentre): “Blood group $O$ rhesus-positive. Serum complement normal. Direct antihuman globulin test positive (anti-gamma and anti-C). Warm autoantibodies present with anti-C and anti-e specificity and a non-specific component."

The patient was treated with prednisone $60 \mathrm{mg}$. daily and withdrawal of mefenamic acid, and made a rapid response. His direct antihuman globulin test was still weakly positive three months after the onset of his anaemia, and has since been negative.

\section{Antihuman Globulin Tests on Treated Patients}

Direct antihuman globulin tests were done on the red cells of 36 patients who had been treated with mefenamic acid continuously for at least three months. Thirty patients were attending a rheumatology clinic and six were being treated by their general practitioners. There were 22 women and 14 men, aged between 30 and 84 years, with a mean age of 55 years. Twenty-five were suffering from rheumatoid arthritis, four from osteoarthritis, and the remainder from miscellaneous rheumatic conditions, including Reiter's syndrome, systemic lupus erythematosus, and psoriatic arthritis. The average daily dose was $1.5 \mathrm{~g}$. daily, with a range from 0.75 to $2 \mathrm{~g}$. daily; and the duration of treatment ranged from 3 to 31 months, with a mean of 13 months.

One patient with rheumatoid arthritis was found to have a positive antihuman globulin test, using a broad-spectrum antihuman globulin serum, on one occasion, but this was subsequently negative despite continuing mefenamic acid therapy. 


\section{In-vitro Studies}

Inhibition and Enhancement Tests.-Attempts were made to inhibit the antibodies in the patient's serum by previous incubation with the sodium salt of mefenamic acid and two of its principal metabolites, the techniques described by Worlledge et al. (1966) being used. Further experiments to demonstrate enhancement of antibody activity were made with use of normal red cells after preincubation with mefenamic acid sodium and its derivatives, the techniques of Worlledge et al. (1966) again being used. Concentrations of mefenamic acid sodium ranging from 1.56 to $100 \mathrm{mg} . / 100 \mathrm{ml}$. in buffered saline at $p H 7.4$ were used in these experiments. The two metabolites were used in similar concentrations. Serum from the first patient only was used for these experiments, specimens being taken during the acute episode of haemolysis and one month after cessation of mefenamic acid therapy and stored at $-20^{\circ}$ C. until use.

Heinz Body Formation.-As Heinz bodies were present in the red cells of one of the patients attempts were made to induce Heinz body formation in normal red cells by incubating them with mefenamic acid sodium and its derivatives. Fresh heparinized normal group $O$ cells were washed in buffered saline and then incubated in an equal volume of phosphate buffer $p H$ 7.4, to which different concentrations of mefenamic acid or its derivatives had been added, for up to six hours at $37^{\circ} \mathrm{C}$. Concentrations of mefenamic acid ranging from 1.56 to $100 \mathrm{mg} . / 100 \mathrm{ml}$. in phosphate buffer were used. Tests for Heinz bodies were made with supravital staining with methyl violet as described by Dacie and Lewis (1963).

Results. - No inhibition of antibody activity was detected after preincubation of the patient's serum with mefenamic acid or its derivatives. Similarly, preincubation of normal cells with these compounds did not enhance the antibody activity. No Heinz bodies were found in normal red cells after six hours' incubation with mefenamic acid or its derivatives.

\section{Discussion}

Though it is not possible to be certain that the autoimmune haemolytic anaemia in these three patients was due to mefenamic acid there is evidence to suggest a causal relation between the drug and the anaemia. All three patients had been taking mefenamic acid for a long period and all had a swift and complete haematological remission as soon as the drug was withdrawn, though two were treated with prednisolone and one with azathioprine. None of the three patients has relapsed in over 12 months from the initial haemolytic episode, and in each the direct antihuman globulin test has become negative. Two patients were treated with steroids initially, but they remained asymptomatic when these were withdrawn. The third patient developed autoimmune haemolytic anaemia while being treated with steroids for rheumatoid arthritis, and his rapid haematological response after withdrawal of mefenamic acid cannot be attributed to these drugs. It is of interest that two of the patients developed diarrhoea coincidentally with the autoimmune haemolytic anaemia. Though diarrhoea is the commonest complication of mefenamic acid, it almost invariably occurs within two weeks of starting treatment.

Two of the patients had rheumatoid arthritis, but autoimmune haemolytic anaemia seldom occurs in this disease unless it is associated with systemic lupus erythematosus (Dacie, 1962), of which there was no evidence in this patient. The remaining patient was not suffering from any condition known to be associated with secondary autoimmune haemolytic anaemia and none has subsequently developed any such disease.
Of the drugs known to cause immune lysis methyldopa is unique in that the antibodies concerned will react with normal red cells in the absence of the drug or its metabolites (Worlledge, et al., 1966). If mefenamic acid was responsible for the autoimmune haemolytic anaemia in the described cases then its mode of action would seem to be similar to that of methyldopa. Antibodies could be eluted easily from the patient's red cells and were then able to sensitize normal red cells, and antibody could be detected in the serum up to five months after the last dose of the drug. In all three cases the antibodies were principally of the warm $\gamma \mathrm{G}$ type and contained some rhesus specificity.

Similar serological findings have been described in methyldopa haemolytic anaemia (Worlledge et al., 1966 ; LoBuglio and Jandl, 1967), and the workers have also shown that the methyldopa antibody is not inhibited by preincubation with methyldopa or its metabolites. Mefenamic acid is N-2,3-xylylanthranilic acid and is chemically dissimilar to methyldopa.

Carstairs, Breckenridge, Dollery, and Worlledge (1966) have shown that $20 \%$ of patients treated with methyldopa have a positive direct antihuman globulin test without evidence of overt haemolysis and Louis, Doyle, Jerums, and KincaidSmith (1967) have found a comparable incidence. The incidence of positive direct tests depends on the dose of the drug and the duration of treatment. In the present investigation only onc patient out of 36 treated with mefenamic acid for more than three months was found to have a positive direct antikuman globulin test, and this was subsequently found to be negative.

The importance of autoimmune haemolytic anaemia as a complication of mefenamic acid depends on whether it is a useful drug for long-term treatment. In clinical trials Cahill, Hill, Jessop, and Kendall (1965), Barnardo, Currey, Mason, Fox, and Weatherall (1966), and Myles, Bacon, and Williams (1967) have suggested that it is of comparable value to aspirin and phenylbutazone, but has a very low incidence of upper intestinal side-effects, which are common with the majority of drugs used in chronic rheumatic diseases. In view of the possible relation between mefenamic acid and haemolytic anaemia long-term therapy with this drug should be undertaken with caution and the patients should be watched carefully for evidence of haemolysis.

We thank Dr. A. F. Ollerenshaw, the Group Laboratory, Preston, for permission to publish details of Case 3, and Dr. O. Savage, West London Hospital, for permission to study patients in his care. We also thank Dr. J. A. L. Gorringe, of Parke Davis and Co., for providing specimens of mefenamic acid and its derivatives for in-vitro studies and Professor G. Wetherley-Mein for his helpful advice.

\section{REFEREXCES}

Barnardo, D. E., Currey, H. L. F., Mason, R. M., Fox, W. R., and Weatherall, M. (1966). Brit. med. F., 2, 342.

Cahill, W. J., Hill, R. D., Jessop, J., and Kendall, P. H. (1965). Ann. phys. Med., 8, 26.

Carstairs, K. C., Breckenridge, A., Dollery, C. T., and Worlledge, S. M.

(1966). Lancet, 2, 133 .
Dacie, J. V. (1962). The Haemolytic Anaemias, Pt. 2. London.

Dacie, J. V., and Lewis, S. M. (1963). Practical Haematology, 3rd ed. London.

LoBuglio, A. F., and Jandl. J. H. (1967). New Engl. f. Med., 276, 658. Louis. W. J., Doyle, A. E., Jerums, G., and Kincaid-Smith, P. (1967). Med. F. Aust., 2, 104.

Myles, A. B., Bacon, P. A., and Williams, K. A. (1967). Ann. rheum. Dis., 26, 494.

Worlledge, S. M., Carstairs, K. C., and Dacie, J. V. (1966). Lancet, 2. 135. 